\title{
Collagen, fibrinogen and thrombin biological addesive is effective in treating experimental liver injuries
}

\section{0 adesivo biológico de colágeno, fibrinogênio e trombina é eficaz no tratamento de lesões hepáticas experimentais}

Frederico Michelino de Oliveira', Marcus Vinícius H. de Carvalho', Evaldo Marchi', Clóvis Antônio lopes Pinto².

A B S T R A C T

\begin{abstract}
Objective: to evaluate the effectiveness of a collagen-based adhesive associated with fibrinogen and thrombin in experimental liver injury in rats. Methods: the study included 30 Wistar rats randomly divided into three groups: $A, B$ and $C$. All underwent standard liver traumatic injury. In group $A$ the lesion was treated with the adhesive; in group $B$, with conventional absorbable suture; and in group $C$, there was no treatment. We analyzed the time of hemostasis, mortality, occurrence of adhesions and any histological changes. Results: there was no statistical difference in relation to mortality $(p=0.5820)$. The group treated with the adhesive showed the lowest hemostasis times $(p=0.0573$, odds ratio 13.5) and lower incidence of adhesions $(p=0.0119)$. Microscopic histological alterations of Groups $A$ and $B$ were similar, with foreign body granuloma formation separating the adhesive material or the suture from the hepatic stroma. Conclusion: the adhesive of collagen associated with fibrinogen and thrombin was effective in the treatment of experimental hepatic injury, providing a lower incidence of adhesions between the liver and surrounding structures.
\end{abstract}

Keywords: Wounds and Injuries. Liver. Hemostatics. Thrombin. Tissue Adhesives.

\section{INTRODUCTION}

$T^{\mathrm{T}}$ he surgical techniques to approach liver bleeding include local compression, cauterization, bandages, sutures, resections and drainage ${ }^{1,2}$. For complex liver lesions accompanied by hemodynamic instability, laparotomy is indicated for bleeding control, with Pringle maneuver ${ }^{2-4}$, ligation of affected vessels and ducts as described by Patcher $^{2}$ and even damage control surgery ${ }^{5}$.

The development of a wide variety of hemostatic agents and tissue adhesives within the last 6 years has been offering surgeons the opportunity to use these products in order to achieve quicker and easier bleeding control. The seriousness and the difficulty in conducting certain cases of liver trauma brings the motivation for the search for new therapeutic alternatives, especially for bleeding control. The efficiency of the new hemostatic agents led to the hypothesis of testing the efficacy of the biological adhesive made of collagen associated with fibrinogen and thrombin, comparing it with the conventional suture in the treatment of experimental traumatic liver injury.

\section{METHODS}

This experimental study was approved by the Ethics Committee for Animal Use of the Faculty of Medicine of Jundiaí under number 81/110.

We included 30 adult, male Wistar rats with a mean age of 3.55 months, weighing on average $442,80 \mathrm{~g}$ (342g - 527g). We randomly divided the animals into three groups, A, B and C, with ten subjects each.

All rats received premedication with atropine at a dose of $0.05 \mathrm{mg} / \mathrm{kg}$ subcutaneously in the dorsal region and acepromazine $1 \mathrm{mg} / \mathrm{kg}$ by the same route. After 15 minutes of premedication they received an association of Tiletamine and Zolazepan $20 \mathrm{mg} / \mathrm{kg}$ intramuscularly. We initiated the surgical procedure after full action of anesthetic drugs, monitored by loss of corneal and eyelid reflexes and limbs bending.

All rats underwent laparotomy under aseptic technique, started from the xiphoid process with about three centimeters long. After opening the abdominal wall, we placed a small orthostatic retractor and identified the liver, the organ chosen for performing a

1 - Department of Surgery, Faculty of Medicine of Jundiaí (FMJ), Jundiaí, SP, Brazil. 2 - Department of Morphology and Basic Pathology, Faculty of Medicine of Jundiaí (FMJ), Jundiaí, SP, Brazil. 

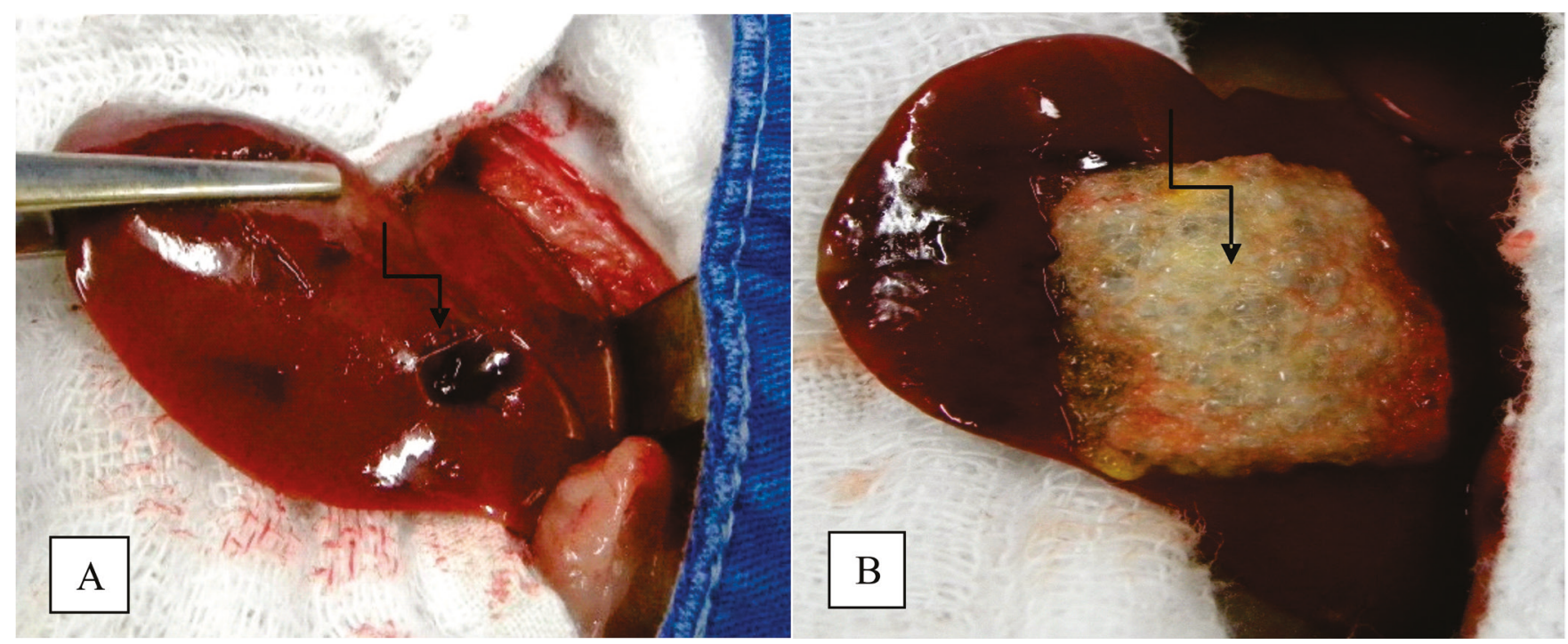

Figure 1. A: Photograph showing hepatic injury (Increase 2x). B: Photograph showing the final appearance of the adhesive (arrow) on the liver injury (Increase 2x).

standardized trauma with a biopsy surgical instrument (Punch Keyes ${ }^{\circledR}$ - ABC instrumentos cirúrgicos, Brazil) of $5 \mathrm{~mm}$ diameter, introduced $5 \mathrm{~mm}$ in depth in the parenchyma (Figure 1A).

Since then the animals received the treatment according to the group they belonged to. Group A: After 1 minute of bleeding, we treated the lesion with the collagen surgical adhesive associated with fibrinogen and thrombin, previously activated in $0.9 \%$ saline (Figure 1B), followed by cleaning of the cavity and abdominal wall closure. Group B: After 1 minute of bleeding, we performed the treatment of the lesion with suture of the liver parenchyma using 3-0 polyglactin-910, (Vicryl@- Ethicon, USA), with subsequent cleaning of the cavity and abdominal wall closure. Group C: control group, we did not carry out any treatment of the hepatic injury, only closing the abdominal wall.

In the experiments in groups $A$ and $B$, we recorded the hemostasis times for further analysis. Postoperatively, all rats received analgesia with dipyrone drops added to water and diet with appropriate chow at will. After eight weeks, we euthanized the surviving rats in a carbon dioxide chamber, with immediate necropsy for observation of intra-abdominal conditions and removal of the liver for histological analysis.

The variables studied were the time to hemostasis, the occurrence of deaths, the occurrence of adhesions and any histological changes.
The hemostasis time was the time required to control bleeding, recorded in groups A and B. For group $C$ the hemostasis time was not recorded, since we closed the abdominal wall immediately after the liver injury. In the study design, we decided not to interfere in any way in the hemostasis of the control group injuries. We feared that, during the bleeding observation to record the time of hemostasis, if there was a bulkier bleeding, the researcher would feel motivated to compress or soak up the blood with gauze. Attitudes like these would interfere with the results, with a tendency to decrease the degree of adhesions.

We classified adhesions into five grades, adapting the classification described in 1964 by Mazuji, Kalambaheti and Pawar?: Grade 0: no adhesion; Grade I: adhesion between the liver injury site and the abdominal wall, small and irregular; Grade II: adhesion of the liver injury site with the abdominal wall and omentum, of moderate intensity and easy separation; Grade III: adhesion of the liver injury site with the abdominal wall, omentum and intestinal loop, intense and of difficult separation; Grade IV: adhesion of the liver wound site to any other region, very intense, homogeneous and difficult to separate. After analysis of the adhesions, were removed the rats livers and placed them in 10\% formalin with subsequent preparation of slides with hematoxylin-eosin and picrosirius for microscopic analysis. 

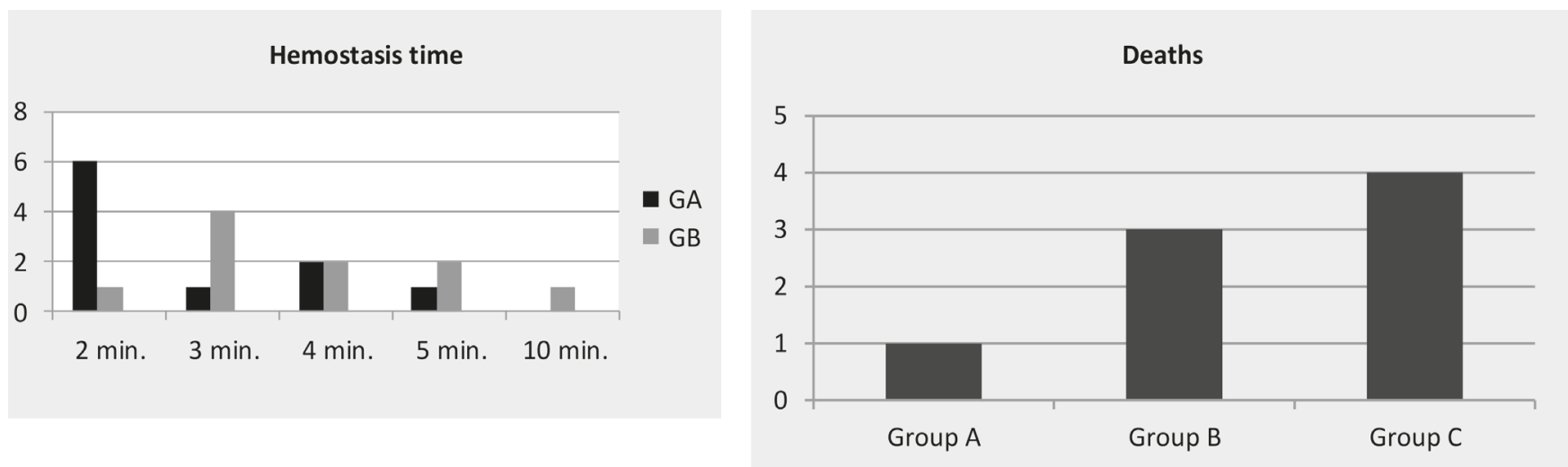

Figure 2. A) distribution of injuries' repair times among the groups $A$ and $B$. In the vertical axis, the number of rats, and in the horizontal, the repair times in minutes. B: distribution of deaths among the all groups. In the vertical axis, the number of deaths, and in the horizontal, the groups.

We performed the statistical analysis with the presentation of tables of absolute (n) and relative (\%) frequency distributions for all variables.

We analyzed the variables death, hemostasis time and occurrence of adhesions by the Fisher exact test. For the qualitative variable death, we used the Fisher's exact test because the conditions of application of the Chi-square test were not met. For the variable time of hemostasis, we compared the occurrence of shorter time, which was 2 minutes, between the two groups (Adhesive and Suture) using the Fisher exact test, since it is a qualitative variable, we also calculated the odds ratio, with its respective confidence interval. The significance level for the statistical tests was $5 \%$.

\section{RESULTS}

\section{Hemostasis Time}

The overall average was 3.5 minutes (range 2-10). Group A had a mean time of 2.4 minutes (range 2-5). Group B showed an average time of 4.2 minutes (range 2-10). The distribution of the occurrence of hemostasis times for each group is shown in Figure 2A.
When we grouped and analyzed the results with time equal to two minutes and time longer than two minutes in groups A and B (Table 1), we obtained a borderline significance between them with the Fisher's exact test $(p=0.0573)$, and when we calculate the odds ratio, the result was 13.5 (range 1.2015.2), which means that group B was 13.5 times more likely to have hemostasis time more than two minutes. Therefore, this data shows statistical significance.

\section{Death}

Group A showed a mortality of $10 \%(1 / 10$ animals), group $B, 33.3 \%$ (3/10 animals), and group $C$ had a $40 \%$ mortality (4/10 animals). The overall mortality rate was $26.67 \%$ (8/30 animals). Table 2 and Figure 2 show the distribution of the number of deaths in each group.

When we compared, by the Fischer's exact test, group $A$ with group $B(p=0.5820)$, group $A$ with group $C(p=0.3034)$ and group $B$ with group $C$ $(p=1.0000)$, we did not identify any difference with statistical significance.

Table 1. Distribution of hemostasis times equal to two minutes and larger than two minutes in groups $A$ and $B$.

\begin{tabular}{lccc}
\hline & 2 minutes & $>2$ minutes & Total \\
\hline Group A & $6(60 \%)$ & $4(40 \%)$ & $10(100 \%)$ \\
Group B & $1(10 \%)$ & $9(90 \%)$ & $10(100 \%)$ \\
Total & $7(35 \%)$ & $13(65 \%)$ & $20(100 \%)$ \\
\hline
\end{tabular}

$p=0.0573$, Odds Ratio $=13.5$, 
Table 2. Distribution of deaths in each group.

\begin{tabular}{lcccc}
\hline & Group A & Group B & Group C & Total \\
\hline Deaths $(\mathrm{n})$ & 1 & 3 & 4 & 8 \\
Deaths $(\%)$ & 10 & 33.3 & 40 & 26.67 \\
\hline
\end{tabular}

\section{Adhesions}

Group A had three rats with Grade 0 adhesions and six with Grade I. Group B had two rats with Grade I adhesions, three with Grade II and two with Grade III. Group C had a rat with Grade I adhesions, four with Grade II and one with Grade III. No rat showed Grade IV adhesions.

Table 3 shows the distribution of occurrence of the degrees of adhesions in each study group.

When we performed the statistical analysis of variable adhesion, we found that group A had a lower incidence than group $B$, with statistical significance and analyzed by Fisher's exact test ( $p=0.0119)$. We observed a similar result when comparing Group A with Group $C$ $(p=0.0069)$.

When comparing Group B with Group C, we found no statistically significant difference $(p=1.0000)$.

\section{Histological changes.}

The histological changes found in the livers' slides of rats from Group A were: reaction of foreign body with formation of histiocytes palisade, separating the amorphous material (adhesive) from the liver cells stroma (Figure 3); plasma cell infiltration and extravasation of bilirubin due to ductal injury. We also observed intense collagen deposition (Figure 4), with dense fibrosis.

The histological changes found in the livers' slides of rats from Group B were foreign body granulo- ma-type inflammatory reaction around the suture fragments, with giant cells and absent fibrosis.

The slides of the rats in group $C$ showed extravasation of red blood cells, without formation of inflammatory tissue.

\section{DISCUSSION}

The induced liver injury tried to reproduce intermediate lesions that correspond to grade III lesions, compared to the liver trauma classification of the American Association for the Surgery of Trauma (AAST) 1,3,8.

For the choice of tissue adhesive, we looked for a product that could take advantage of the bleeding barrier properties, offered by mechanical hemostatic agents, associated with direct action on blood clotting, offered by active hemostatic agents. So the choice fell on a combination of products, already on the market, represented by the combination of collagen combined with fibrinogen and thrombin ${ }^{9-13}$. This is a totally biological product, without the use of synthetic components. This adhesive was evaluated in clinical studies in support of hemostasis in different kinds of surgery, most often in elective situations, especially in parenchymatous organs, showing effectiveness in bleeding control9-13.

Frilling, in 2005, reported superiority of adhesive compared with argon beam during liver resection regarding time of hemostasis ${ }^{12}$. We obtained similar

Table 3. Distribution of adhesions degrees.

\begin{tabular}{lccc}
\hline & \multicolumn{3}{c}{ ADHESIONS } \\
\cline { 2 - 4 } & Group A & Group B & Group C \\
\hline Grade zero & 3 & 0 & 0 \\
Grade I & 6 & 2 & 1 \\
Grade II & 0 & 3 & 4 \\
Grade III & 0 & 2 & 1 \\
Grade IV & 0 & 0 & 0 \\
\hline
\end{tabular}




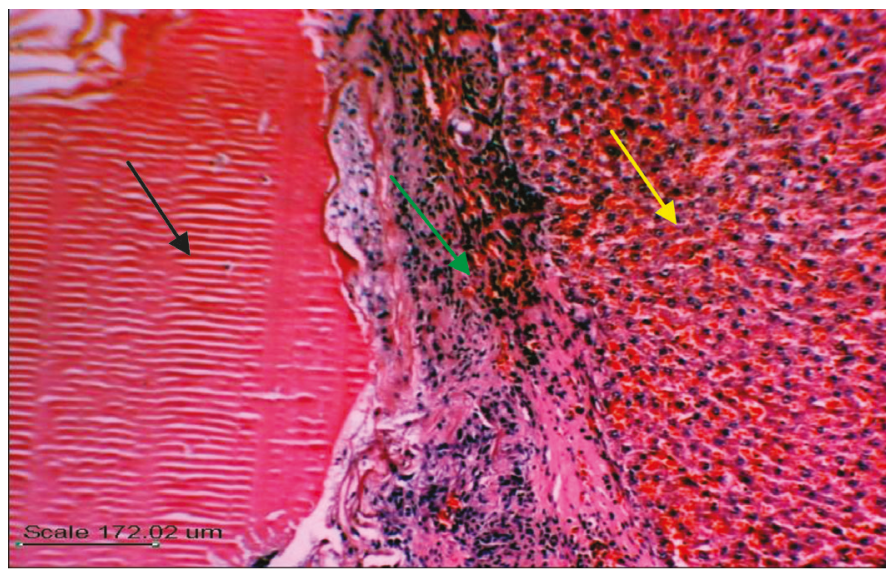

Figure 3. Photomicrograph of histological section stained with hematoxylin-eosin, showing a group A rat's liver. The black arrow points to the area of foreign-body inflammatory process granuloma, with histiocytes distributed in Palisade, separating the liver stroma from the adhesive material. points to the amorphous adhesive material; the green arrow

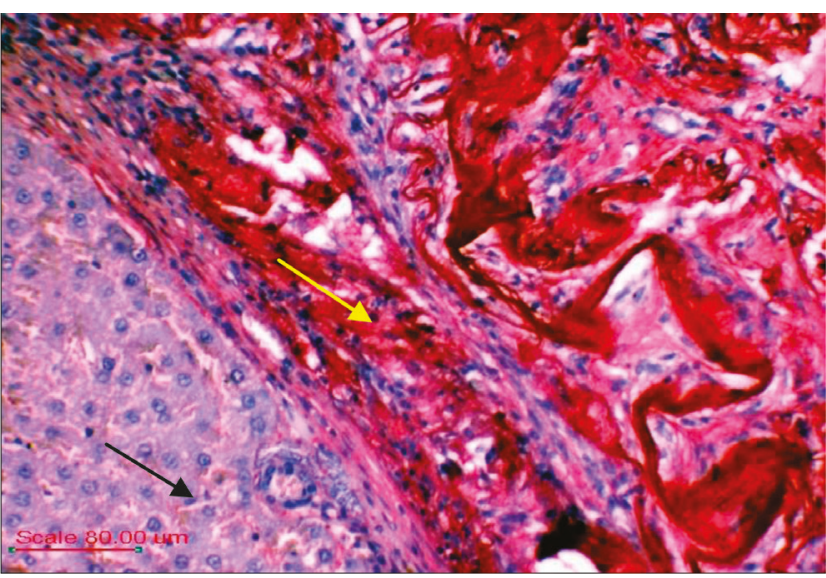

Figure 4. Photomicrograph of histological section of the biochemical reaction of Masson's trichrome, showing a group A rat's liver. The yellow arrow points to collagen fibers stained in red permeating lymphonuclear inflammatory cells and giant cells; the black arrow points to the hepatic parenchyma.

The occurrence of adhesions, which can be classified as a complication of surgical treatment, was statistically lower in the group treated with the adhesive compared with the one treated with suture $(p=0.0119)$. This may be due to the fact that the animals treated with suture presented major bleeding and bruising at the site of injury, resulting in greater inflammatory reaction and consequent adhesions.

Frena and Martin ${ }^{13}$, in 2006, found no biliary fistulas with the use of this product in electives hepatectomies in humans, a fact that also occurred in our study, even when dealing with liver trauma, which increases the chance of this type of complication.

The mortality of the group treated with the adadhesive, other hemostatic agents are also cited as effective in the control of various types of bleeding. Garza and Rumsey, in 1990, showed effectiveness in bleeding control with the use of fibrin glue in two patients suffering from liver trauma ${ }^{15}$. In the same year, Oschner et al. used this product in 26 victims of hepatic and splenic trauma, also with effective control of bleeding $^{16}$.

Several experimental studies show the effectiveness of fibrin adhesive in controlling hepatic hemorrhage in $\operatorname{dogs}^{17}$, pigs ${ }^{18,19}$, rats $^{20}$ and rabbits ${ }^{21}$, with good adhesion to the injured liver, little local inflammatory reaction and few complications. In our study we obtained findings similar to those. hesive $(10 \%)$ showed no statistically significant difference
from the group treated with suture $(33.3 \%, p=0.5820)$ and the control group (40\%, $p=0.3034)$. In a study of 1,000 patients suffering from liver trauma led by Feliciano and Mattox between 1979 and 1984, they found that mortality was $10 \%{ }^{22}$. In another study conducted by Saaiq et al. in Islamabad, Pakistan, between 2003 and 2010, the mortality rate was $9.73 \%{ }^{23}$. Thus, mortality with the adhesive experimental use was similar to those found in liver trauma treatments conventionally performed in humans.

The presence of foreign-body inflammatory reaction found in the histological analysis of the livers of rats treated with the collagen adhesive associated 
with fibrinogen and thrombin was similar to changes found in studies using fibrin glue in rats ${ }^{24}$, fibrin glue in rabbits ${ }^{21}$ and polyglycolic acid mesh in pigs ${ }^{25}$. We did not find histological findings suggestive of necrosis of the liver tissue or vacuolar degeneration, as described with the use of cyanoacrylate ${ }^{26}$, or abscesses near the adhesive areas. The intense collagen deposition near identified the adhesive use areas (Figure 3 ) is an important fact, if we consider that collagen is essential for the injured tissue repair process ${ }^{24}$.

Conservative treatment of isolated liver trauma has been increasingly performed in recent decades, reaching levels of $80 \%$ in the present day ${ }^{27}$. This fact, associated with the development of less invasive therapies, such as angiography with embolization ${ }^{28,29}$, decreases the need for surgery to control liver bleeding. But in situations of hemodynamic instability or associated trauma in other organs, particularly in hollow viscus, the surgical treatment is often mandatory $13,8,22,27,28$. The liver surgical approach can be complex, requiring great skill and experience of the surgeon ${ }^{2}$. The conducted study showed that collagen adhesive associated with fibrinogen and thrombin was effective in the treatment of traumatic liver injury in rats and has the potential to be used by sur- geons during the same approach in humans. The ease of handling of the adhesive compared with suturing the liver tissue, leading to diminished bleeding control time and low occurrence of complications, are the main points favorable for this material.

There was no significant difference in mortality when comparing the adhesive use with the suture and the no treatment. The collagen adhesive associated with fibrinogen and thrombin was superior to suture regarding hemostasis time, reflecting easy handling of the material and effective bleeding control. The adhesive was also superior to suture and no treatment in relation to the occurrence of adhesions. When we analyzed the histological changes, we did not identify any damage to liver tissue related to the use of the adhesive.

We conclude that the treatment with collagen adhesive associated with fibrinogen and thrombin was effective in experimental hepatic injury, opening new perspectives for use in liver injury in humans.

\section{ACKNOWLEDGEMENT}

We thank Professor Siani Sirlei Morais for the statistical analysis of this study.

\title{
R E S U M O
}

\begin{abstract}
Objetivo: avaliar a eficácia de um adesivo à base de colágeno associado a fibrinogênio e trombina, no trauma hepático experimental em ratos. Métodos: foram incluídos no estudo 30 ratos Wistar, igualmente divididos aleatoriamente em três grupos: A, B e C. Todos foram submetidos à lesão traumática hepática padronizada. No grupo A a lesão foi tratada com o adesivo, no grupo B com sutura convencional com fio absorvível e no grupo C não houve tratamento da lesão. Foram analisados o tempo de hemostasia, mortalidade, ocorrência de aderências e eventuais alterações histológicas. Resultados: os resultados mostraram que não houve diferença estatística em relação à mortalidade $(p=0,5820)$. O grupo tratado com adesivo apresentou os menores tempos de hemostasia $(p=0,0573$ e odds ratio 13,5$)$ e menor ocorrência de aderências $(p=0,0119)$. Microscopicamente, as alterações histológicas dos grupos $A$ e B foram semelhantes, com a formação de granuloma de corpo estranho separando o material do adesivo e do fio de sutura do estroma hepático. Conclusão: o estudo concluiu que o adesivo de colágeno associado a fibrinogênio e trombina foi eficaz no tratamento do trauma hepático experimental, proporcionado menor ocorrência de aderências entre o fígado e as estruturas vizinhas.
\end{abstract}

Descritores: Ferimentos e Lesões. Fígado. Hemostáticos. Trombina. Adesivos Teciduais.

\section{REFERENCES}

1. Piper GL, Peitzman AB. Current management of hepatic trauma. Surg Clin N Am. 2010;90(4):775-85.

2. Feliciano DV, Pachter HL. Hepatic trauma revisited. Curr Probl Surg. 1989;26(7):457-524.

3. Moore EE. Edgar J. Poth Lecture.Critical decisions in the management of hepatic trauma. Am J Surg. 1984;148(6):712-6.

4. Pringle JH. Notes on the arrest of hepatic hemorrhage due to trauma. Ann Surg. 1908;48(4):541-9.

5. Weber DG, Bendinelli C, Balogh ZJ. Damage control surgery for abdominal emergencies. Br J Surg. 2014;101(1):e109-18. 
6. Archneck HE, Sileshi B, Jamielkowski RM, Albala DM, Shapiro ML, Lawson JH. A comprehensive review of topical hemostatic agents: efficacy and recommendations for use. Ann Surg. 2010;251(2):217-28.

7. Mazuji MK, Kalambaheti K, Pawar B. Preventive of adhesions with polyvinylpyrrolidone. Preliminary report. Arch Surg. 1964;89(6):1011-5.

8. Rasslan S, Monteiro RP. Tratamento não operatório do trauma hepático. Rev Col Bras Cir. 1999;26(6):379-87.

9. Schelling G, Block T, Gokel M, Blanke E, Hammer C, Brendel W. Application of a fibrinogen-thrombin-collagen-based hemostyptic agent in experimental injuries of liver and spleen. J Trauma. 1998;28(4):472-5.

10. Grottke O, Braunschweig T, Daheim N, Coburn M, Grieb G, Rossaint R, et al. Effect of Tacho Sil in a coagulopathic pig model with blunt liver injuries. J Surg Res. 2011;171(1):234-9.

11. Erdogan D, van Gulik TM. Evolution of fibrinogen-coated collagen patch for use as a topical hemostatic agent. J Biomed Mater Res B Appl Biomater. 2008;85(1):272-8.

12. Frilling $A$, Stavrou $G A$, Mischinger $H J$, de Hemptinne B, Rokkjaer M, Klempnauer, et al. Effectiveness of a new carrier-bound fibrin sealant versus argon beamer as haemostatic agent during liver resection: a randomized prospective trial. Langenbecks Arch Surg. 2005;390(2):11420.

13. Frena A, Martin F. How to improve bilio-stasis in liver surgery. Chir Ital. 2006;58(6):793-5.

14. Mantovani M, Vidal BC, Concon Filho A. Tamponamento das lesões hepáticas transfixantes com colágeno tipo I. Acta Cir Bras. 1998; 13(2):80-5.

15. de la Garza JL, Rumsey E Jr. Fibrin glue and hemostasis in a liver trauma: a case report. J Trauma. 1990;30(4):512-3.

16. Oschsner MG, Maniscalco-Theberge ME, Champion HR. Fibrin glue as a haemostatic agent in hepatic and splenic trauma. J Trauma. 1990;30(7):884-7.

17. Kram HB, Reuben $B I$, Fleming AW, Shoemaker
WC. Use of fibrin glue in hepatic trauma. J Trauma. 1988;28(8):1195-201.

18. Feinstein AJ, Varela JE, Cohn SM, Compton RP, McKenney MG. Fibrin glue eliminates the need for packing after complex liver injuries. Yale J Biol Med. 2001;74(5):315-21.

19. Delgado AV, Kheirabadi BS, Fruchterman TM, Scherer M, Cortez D, Wade CE, et al. A novel biologic hemostatic dressing (Fibrin Patch) reduces blood loss and resuscitation volume and improves survival in hypothermic, coagulopathic swine with grade $V$ liver injury. J Trauma. 2008;64(1):75-80.

20. Jakob H, Campbell CD, Stemberger A, WriedLubre I, Blumel G, Replogle RL. Combined application of heterologous collagen and fibrin sealant for liver injuries. J Surg Res. 1984;36(6):571-7.

21. Taha MO, Rosa K, Fagundes DJ. The role of biological and adhesive and suture material on rabbit hepatic injury. Acta Cir Bras. 2006;21(5):310-4.

22. Feliciano DV, Mattox KL, Jordan GL, Burch JM, Bitondo CG, Cruse PA. Management of 1000 consecutive cases of hepatic trauma (19791984). Ann Surg. 1986;204(4):438-45.

23. Saaiq $M$, Niaz-ud-Din, Zubain $M$, Shah SA. Presentation and outcome of surgically managed lives trauma: experience at a tertiary care teaching hospital. J Park Med Assoc. 2013;63(4):436-9.

24. Fontes CER, Taha MO, Fagundes DJ, Ferreira MV, Prado Filho OR, Mardegan JM. Estudo comparativo do uso de cola de fibrina e cianoacrilato em ferimento de fígado de rato. Acta Cir Bras. 2004; 19(1):37-42.

25. Bakker FC, Wille F, Patka P, Haarman HJ. Surgical treatment of liver with an absorbable mesh: an experimental study. 1995;38(6):891-4.

26. Silveira LMG, Matera A, Cortopassi SRG, Ferrigno CRA, Xavier JG, Cunha FM. Comparação entre os efeitos da associação gelatina-resorcina-formaldeído e do n-butil-2-cianoacrilato na síntese do parênquima hepático de coelhos. Braz J Vet Res Anim Sci. 2005;42(4):284-90.

27. Ahmed N, Vernick JJ. Management of liver trauma 
in adults. J Emerg Trauma Shock. 2011;4(1):114-9.

28. Bouras AF, Truant S, Pruvot FR. Management of blunt hepatic trauma. J Visc surg. 2010;147(6):e351-8.

29. Misselbeck TS, Teicher EJ, Cipolle MD, Pasquale MD, Shah KT, Dangleben DA, et al. Hepatic angioembolization in trauma patients: indications and complications. J Trauma. 2009;67(4):769-73.
Received in: 13/03/2016

Accepted for publication: 26/06/2016

Conflict of interest: none.

Source of funding: none.

\section{Mailing address:}

Marcus Vinicius H. de Carvalho

E-mail: marcus.carvalho@sbccv.org.br 